\title{
Developing an Android-Based Mobile Application for Civic Education Learning
}

\author{
https://doi.org/10.3991/ijim.v14i16.14967 \\ Mukhamad Murdiono ${ }^{\varpi}$, Suyato, Elly Nur Rahmawati, Muhammad Abdul Aziz \\ Universitas Negeri Yogyakarta, Yogyakarta, Indonesia \\ mukhamad_murdiono@uny.ac.id
}

\begin{abstract}
This research aims at developing an android-based mobile application to assist the teaching-learning process of civic education in senior high schools. This research is a research and development (R\&D) which employs the ADDIE model (Analysis, Design, Development, Implementation, and Evaluation). The research results show that the developed application is very feasible to be used $(89.04 \%$ ) based on the material expert's judgment. In addition, the media expert's judgment indicate that the application is eligible to be used $(90.78 \%)$. During the large-group trials, the application scored between 3.96 and 4.68, meaning that the developed application is good and very feasible to be utilized for the teaching-learning process of civic education in senior high schools.
\end{abstract}

Keywords-Mobile application, android, civic education.

\section{Introduction}

The rapid development of communication and information technology not only change the lifestyle but also the learning process at schools [1], [2]. With regard to this, teaching is required to incorporate technology to produce more meaningful learning outcomes [3], [4]. Combining technology and pedagogical approach may greatly contibute to the student's achievement on specific knowledge [5]. In addition, using information technology, students no longer find difficulties to get learning materials that are now highly accessible on the internet [6]. The internet allows people all over the world to get broad access to information beyond time zones and administrative borders. Moreover, it provides a platform for the exchange of information and ideas between governments and citizens [7].

Civic education plays a strategic role in developing students' global competencies. Civic education must able to encourage students to develop their identities, engage in the global community and establish human relations worldwide [8]; [9]. Civic education is ultimately aimed at fostering young generation to be smart and good citizens. Good citizens at least possess three main aspects of high-quality civic education, namely: (1) civic knowledge, (2) civic skills, and (3) civic dispositions [10]. Civic 
knowledge is related to what citizens should know. Meanwhile, civic skills include intellectual and participatory skills. Civic dispositions refer to the main public and private characters that citizens possess to preserve and develop the constitutional democracy.

In the context of building global citizenship culture, civic education requires a curriculum that enhances the development of multidimensional citizenship. There are four crucial aspects of multidimensional citizenship which include (1) personal, (2) social, (3) temporal, and (4) spatial. These four aspects become inseparable parts of the development of a multidimensional civic education curriculum [11]. In addition, the curriculum developed at schools needs to enhance the students' digital competencies [12], with which students are expected to be able to play their role as global citizens.

The multidimensional curriculum is believed to be able to produce a generation who has a capacity to face the challenges and solve global problems. In this case, the conception of a broader curriculum needs to be formulated. The social science curriculum must reflect the current state of the society and the historical reality of the world. For this reason, the digital competence of the citizens must be included as a core element in the educational curriculum in the era of communication and information technology advancement [13].

The advancement of information and communication technology in Industry 4.0 era has dramatically changed the world. These changes have posed various problems for the countries worldwide. Therefore, the citizenship inevitably develops into a global citizenship, a multidimensional construction that depends on the interrelationships of social responsibility, global competence, and global involvement [14].

Citizenship or civic education is one of the subjects that consistently evolves in line with the changing times, both in terms of its substance and concept. Based on the researcher's initial interview, students perceive it as a monotonous and less enjoyable subject partly because it requires students to memorize a myriad of concepts while the skills and characters development get less portion. On the other hand, it is a fundamental subject for students since it always evolves along with the changing social and political conditions happening in a country. However, in practice, the teaching process of civic education at schools is less stimulating and teachers still utilize the lecture teaching method dominantly.

The lack of teaching media used in the teaching and learning process improves the student's boredom to the Citizenship subject. With regard to this, teachers need to develop innovative learning media which can enhance active participation of students in learning [15]. Also, improving teacher's capacity to deal with technology application is required to reduce the digital gaps, improve their digital creativity, increase awareness, develop critical thinking, and build a resilience [16]. As the world enters Industry 4.0 era, there has been a growing need for developing an innovative android-based application learning media which enables to improve student's attention and motivation in learning. Many Android-based applications have been developed for educational and other purposes [17], [18], [19]. The mobile devices offer an opportunity for creative use and provide great access to interesting content [20].

The majority of teachers still utilize conventional and less attractive media for teaching civic education subject. In fact, teachers as agents of change in schools are responsible for preparing students to deal with any challenges and problems [21]. Therefore, 
the development of Android-based applications for teaching the Citizenship subject in high schools is required considering that the number of smartphone usage in Indonesia in 2018 has reached 177.9 million with a penetration of $67 \%$ [22]. Moreover, learning media -based mobile operating systems can be easily downloaded from Play Store (for Android users) or App Store (for Apple users). There have been many studies presenting the evidence of the successful use of mobile-based applications in classroom learning [23-25]. In addition, mobile applications can be utilized to enhance environmental education and education for achieving sustainable development [26].

In this research, the developed Android-based application is "LEGASI" which is designed as media to assist high-school teachers to deliver materials on civic education subject such as governmental institutions and systems. This innovation is expected to be able to increase the students' motivation and learning achievement and change the way they learn civic education. Using this learning media, the Citizenship education subject will be more interesting and attractive to students.

\section{$2 \quad$ Literature Review}

\subsection{Civic education learning}

The vision of civic education in the new paradigm places a stronger emphasis on the nation and character building, citizen empowerment, and the development of civil society. While the mission of civic education in the new paradigm is producing good citizens, which have the characteristics of: actively participating in the life of the nation and state, performing civil culture, and having critical and creative thinking [27].

The appropriate learning strategies to achieve these goals include dialogical-critical, direct experiences, collaborative, and cooperative. These learning strategies emphasize three domains of learning, namely: cognitive, affective, and psychomotor. This is in line with the statement of [28] that the aspects of citizenship education consist of knowledge, appreciation, critical thinking skills, communication skills, cooperation skills, and conflict resolution skills. In its implementation, these aspects require a comprehensive approach which includes inculcation, modeling, facilitation, and skills development.

Civics not only focuses on teaching the articles of the Basic Law but also examines the behavior of citizens in relation to other citizens and their natural surroundings. The objects of the Civics Study are citizens in relation to social organization, social, economic, religious, cultural and state. In [29], the object of civic studies consists of behavior, type of thought growth, potential that exists in every citizen, rights and obligations, ideals and aspirations, awareness (patriotism, nationalism, international understanding, moral of Pancasila), activity, participation and responsibility.

\subsection{The nature and objectives of civic education}

The development of civic education in Indonesia cannot be separated from the growth of Civic Education in the United States. Based on the history of Civic Education 
that develop in the United States, the concept of civic education has experienced an expansion from time to time. Historically, Civics lessons were introduced in the United States in 1790 in the framework of "Americanizing" of the American or commonly known as "theory of Americanization" [29]. Then, the term of Civics continued to develop in America with various names, including: Civics, Civic Education, Community Civics, Civic-Citizenship Education. The terms of civics which continue to develop in the United States show that the study of citizenship education is increasingly broad and complex

In a broader perspective, the goal of civic education is not only producing good citizens in a national but also in a global context. The dynamics of development in the 21 st century require a broader conception of the civic education goals. A citizenship education in the global era of the 21 st century needs to be reconceptualized, in order to be able to effectively educate students to be citizens who can carry out their duty properly. In order to succeed the reform of civic education, a great change from academic knowledge to transformative academic knowledge is required [9].

The detail objectives of civic education are elaborated in the decree of the Minister of National Education Number 22 of 2006 concerning the Content Standards [30]. The decree explains that the objectives of civic education are to equip students in order to have the following abilities:

a) Think critically, rationally, and creatively in responding to the issues of civics

b) Participate actively and responsibly, and act intelligently in community, national and state activities, and anti-corruption activities.

c) Develop positively and democratically to improve his/her capacity based on the characteristics of Indonesian society so that they can live together with other nations.

d) Interact with other nations in the world directly or indirectly by utilizing information and communication technology.

To achieve the objectives of civic education above, civic learning that encourages students to actively participate in the learning process needs to be designed.

\section{$3 \quad$ Methodology}

\subsection{Research setting}

This research was carried out at SMA N 1 Jetis. It is one of the public Senior High Schools in Bantul Regency, Yogyakarta Province, Indonesia. Moreover, the research was conducted in February 2019.

\subsection{Research design}

This research is a research-and-development $(R \& D)$, a scientific method used to produce specific products, or improve the existing products, and test their effectiveness [31]. In general, R\&D is longitudinal, meaning that it employs multiple stages. This research was designed to develop valid, practical, efficient, and effective Citizenship 
learning media that meet the need and curriculum standards for high schools. An Android-based application was designed and developed using the five stages of the ADDIE model, namely, Analysis (A), Design (D), Development (D), Implementation (I), and Evaluation (E).

\subsection{Data analysis}

The research data were analyzed qualitatively and quantitatively. The qualitative analysis employed a descriptive approach while the quantitative analysis utilized the Sign Test analysis to process and interpret the results of the product trials. The Sign Test examined the hypothesis using two comparatives and ordinal data obtained from the responses recorded in the questionnaire and 4-point Likert scale. The percentage of the assessment results on media feasibility is presented in Table 1.

Table 1. The percentage of the media feasibility assessed by the reviewers

\begin{tabular}{|c|l|}
\hline Answers & \multicolumn{1}{|c|}{ Descriptions } \\
\hline $0 \%-20 \%$ & Unfeasible \\
\hline $21 \%-40 \%$ & Less Feasible \\
\hline $41 \%-60 \%$ & Moderately Feasible \\
\hline $61 \%-80 \%$ & Feasible \\
\hline $81 \%-100 \%$ & Highly Feasible \\
\hline
\end{tabular}

The table above indicates that the category for media feasibility include unfeasible, less feasible, moderately feasible, feasible and highly feasible. The percentage for each category is $0 \%-20 \%, 21 \%-40 \%, 41 \%-60 \%, 61 \%-80 \%$, and $81 \%-100 \%$ respectively. The media feasibility is assessed by the reviewers.

\subsection{Data collection techniques}

The data in this research were collected using some techniques which include interviews, questionnaire, and tests. In this research, the researchers interviewed subject teachers and school principals using the interview guidelines which contained some aspects including the instructional media use, learning methods, student characteristics, and learning facilities. The results of the interview were then used as a consideration in the process of media development. Moreover, the questionnaire is addressed for media and material experts. In addition, the tests were divided into two namely, pre-test and post-test. The pre-test were given to students in order to know their initial ability on the learning materials about the surrounding culture before they were taught using instructional media while the post test was carried out to investigate the student's learning outcomes after they were taught using learning media. 


\section{$4 \quad$ Results and Discussions}

The development of android-based mobile application for Civic Education Learning utilizes the ADDIE model consists of 5 stages namely, Analysis, Design, Development, Implementation, and Evaluation. Each stage is described as follows.

\subsection{Analysis}

In this stage, the researchers observed the teaching and learning process of civic education, interviewed some civic subject teachers and students of grade X at SMA N 1 Jetis Yogyakarta. The analysis covers some aspects which include the curriculum, student's need, media used by the teachers, teaching materials for Civic subject. Based on the data, SMA N 1 Jetis implements 2013 curriculum. Teachers utilized lecture and discussion methods aided with power points as learning media. Moreover, the interview results conducted with the students and teachers showed that civic education lesson was perceived as monotonous, less attractive and the materials were difficult to understand.

The research data also reveal that civic education learning still utilizes a teachercentered approach. Teachers cannot foster active student participation in the learning activities, and the learning media used in the classroom are still very limited. The researchers also analyzed the learning materials. One of the teaching materials which was considered difficult by the student was the Indonesian government institution taught in the first semester of the first year.

Referring to the analysis results which are supported with the data gathered from the field, teachers require learning media that help students learn quickly about the Indonesian government institutions. One of the strategies to develop attractive learning media is incorporating technology. For instance, using Facebook or mobile application as a learning media which can promote a meaningful learning in the classroom [32]. The learning media developed in this research is an Android-based application called "LEGASI" that can be downloaded from the Google Play Store. This application is believed to improve the quality of learning in the classroom and are highly effective for improving student learning outcomes [33], [34], [35]. In addition, an Android-based application which has been developed help students with hearing impairments to learn to read the Quran [36]. Based on the analysis of the high school curriculum, the materials developed are relevant with the basic competencies of the Citizenship subject for the first semester of the first year in senior high schools (grade X).

\subsection{Design}

The next stage was designing the application. In this process, the layout was designed using CorelDRAW X7 while the application features were developed utilizing Andromo, a web-based mobile application builder. This stage consists of developing assessment instrument for LEGASI Apps and designing LEGASI Apps. Each is explained as follows. 
Developing assessment instrument for LEGASI apps: The LEGASI Apps assessment instrument is formulated in the form of questionnaire to examine the eligibility of the LEGASI Apps. This instrument is intended to gather data from the material experts, media experts, and students. This instrument uses a Likert scale reference which include 5 categories namely Very Good, Good, Acceptable, Poor, Very Poor.

Designing LEGASI apps: LEGASI consists of some important menus. In the Main Menu, the features are displayed in a solid and smooth theme. This page provides the first impression that invites students to interact with the colorful display and animated illustrations of logos. The Main Menu of the Android-based LEGASI application is presented in Figure 1.
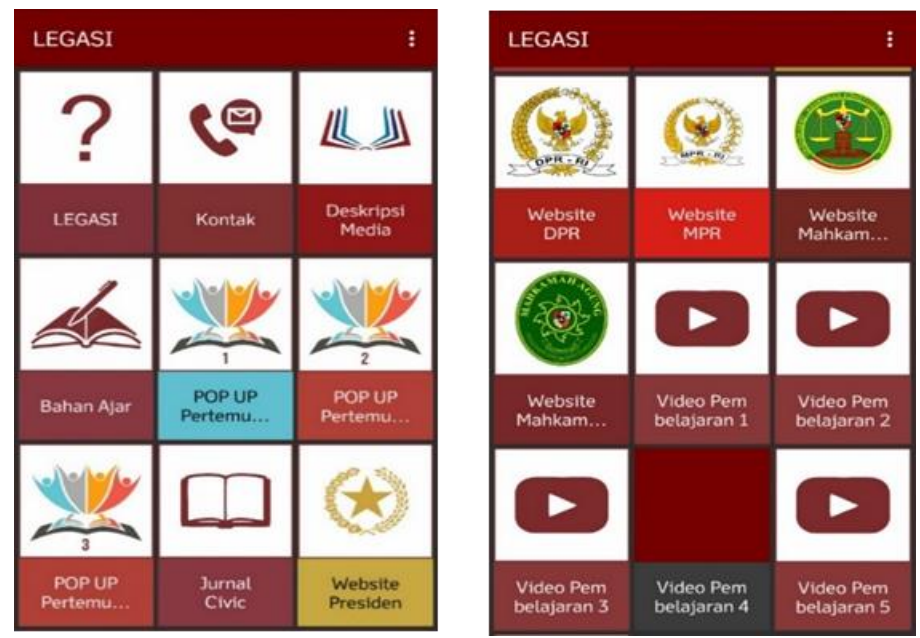

Fig. 1. The Main Menu of LEGASI

Figure 1 (from left to right) shows the Main Menu which consists of About LEGASI, Contact, Description of Media, Teaching Materials, pop-ups, Journal of Civics, websites of government institutions, and learning videos explaining each institution. About LEGASI and Contact provide a brief description of LEGASI, including the names of the application creators. Further information about the application developers can be found on the Contact menu.

"Description of Media" menu presents a clear overview about the media that is interesting for the readers. Also, it lists the core and basic competencies of the Citizenship subject offered by LEGASI as a guideline for teachers to deliver the learning materials. The "Teaching Materials" menu presents a broad overview about the materials explained in the application. The teaching materials are not monotonous as in textbooks; instead, they were developed using a photo editing application and added with animation to increase students' interest in reading.

There are three "digital pop-up" menus which offer different contents. These menus digitized pop up in order to be easily carry and become more interactive. LEGASI offers a more interactive user interface and is conveniently mobile. This menu is displayed attractively and equipped with animations about the Indonesian government institutions 
which were designed particularly for the first-year senior high school students (grade $\mathrm{X}$ ). Utilizing animated design, boring learning activities can be transformed into more enjoyable and interactive learning activities.

When users click the Journal of Civics menu, they will be redirected to the Journal of Civics website owned by the Department of Civic and Legal Education, Faculty of Social Sciences Yogyakarta State University, Indonesia. This journal publishes the results of the latest research on civics, politics, law, and education. This feature provides students with an understanding of scientific findings that have been published in journals so that students can find new information and knowledge about the past and current studies in Civic Science. Also, the Journal of Civics menu may improve students' interest in reading academic articles from the latest research.

The "government institution" menu will direct the users to the websites of the government institutions in Indonesia. This menu was added to LEGASI in order to increase the students' awareness on the most recent information about government institutions in Indonesia. The detail learning materials about each institution can be found from the collection of animated videos that are fascinating to observe and learn, which can be accessed on the Learning Videos menu.

In summary, the design of the LEGASI Apps above has considered some important aspects such as using interesting animations/photos to attract the students' interest, providing complete sources of information, and offering interactive use. This is relevant with the research outcomes where the developed apps is expected to enhance the learning of Civic education subject.

\subsection{Develop}

The next stage was the development stage. This stage comprises of application development and validation. They are presented as follows.

LEGASI apps development: In this stage, the materials were prepared using Microsoft Word program and were designed using CorelDRAW X7 to increase the attractiveness of the application. The design was then imported to Andromo to be included in the previously created menu.

LEGASI apps validation: After the LEGASI apps was successfully finalized, the next step was validating or evaluating its feasibility before testing it to students. In this context, the qualitative data which include suggestions and inputs from validators were analyzed.

The validation of the LEGASI application was carried out by the material and media experts. They are the lecturers at the Department of Civic and Law Education. Material experts assessed the quality of contents and the learning objectives of civic education based on the developed materials in the application and input their responses to the questionnaire designed using a 5-point scale. Also, they were encouraged to provide suggestions and comments to improve the application. The results of validation performed by material experts show that the quality of the contents and objectives was $91.42 \%$, and the application programming was $86.66 \%$. In addition, the results of the media validation from these two aspects reach $89.04 \%$, meaning that the LEGASI application is highly feasible as learning media. 
Media experts were asked to validate and assess to what extent the visual communication and programming contributed to the feasibility of the application by filling out a questionnaire designed using a 5-point scale. Also, they were to give comments and suggestions to improve LEGASI. The results of validation performed by media experts showed that visual communication was $87.27 \%$, while the programming was $94.29 \%$. When both aspects were combined, it showed an average of $90.78 \%$, meaning that the developed application is highly feasible as learning media. Thus, based on the material and media experts, the application was feasible to be used by teachers for teaching in the classroom. Teachers, as agents of change, must be able to utilize multimedia technology therefore they should arm themselves with sufficient digitals skills [37]. The use of multimedia tools and technology in the educational field can improve the quality of education and student development at varying levels [38]. Moreover, the utilization of technology such as appropriate developed software may effectively enhance interactive learning, foster effective learning, and provide joyful learning [39] [40].

\subsection{Implementation}

After the validation, the next stage is implementation. At this stage, the designed and developed learning media was applied. LEGASI was tested to a small group of students at schools. This test involved ten students from the first semester of the first year (Grade $\mathrm{X}$ ) and was carried out after the LEGASI had been revised. These students were selected by the teachers based on the varying abilities: high, moderate, and low. This sampling design was aimed to determine the outcomes of using LEGASI as a learning media for teaching civic education subject. These students were asked to assess the two aspects, namely material and media. The results are summarized in Tables 2 and 3.

Table 2. The Validation Results of the Mobile-based Learning Materials in Small Groups

\begin{tabular}{|c|l|c|c|}
\hline No. & \multicolumn{1}{|c|}{ Indicators } & Scores & Categories \\
\hline 1. & The materials are easy to understand & 4,2 & Good \\
\hline 2. & It facilitates understanding & 4,6 & Good \\
\hline 3. & The materials are suitable & 4,2 & Good \\
\hline 4. & It introduces the Government institutions in details & 4,0 & Good \\
\hline 5. & It motivates students & 4,6 & Good \\
\hline 6. & Students can understand the learning materials & 4,2 & Good \\
\hline
\end{tabular}

Table 3. The Validation Results of the Mobile-based Learning Media in Small Groups

\begin{tabular}{|c|l|c|c|}
\hline No. & \multicolumn{1}{|c|}{ Indicators } & Scores & Categories \\
\hline 1. & Easy to use & 4,4 & Good \\
\hline 2. & Can be used independently & 4,2 & Good \\
\hline 3. & Understandable language & 4,4 & Good \\
\hline 4. & High accessibility & 4,4 & Good \\
\hline 5. & Attractive media & 4,4 & Good \\
\hline 6. & Suitable animation & 4,0 & Good \\
\hline
\end{tabular}


Based on the data presented in Table 2 and 3, LEGASI belongs to the category of very good viewed from the material and media aspects. The score range from 4.0-4.6 indicates that the application was eligible to be tested in large groups. However, before performing these trials, LEGASI was first revised based on the results of the previous small-group trials. The large-group trials were performed to know the feasibility of LEGASI thoroughly. Like the small-group trials, it involved the students with varying levels of ability (i.e., low, moderate, and high) to identify the impact of using LEGASI for students with different academic achievements. The results of the large-group trials are summarized in Table 4 and 5.

Table 4. The Validation Results of the Mobile-based Learning Material in Large Groups

\begin{tabular}{|c|l|c|c|}
\hline No. & \multicolumn{1}{|c|}{ Indicators } & Scores & Categories \\
\hline 1. & The materials are easy to understand & 4,3 & Good \\
\hline 2. & It facilitates understanding & 4,23 & Good \\
\hline 3. & The materials are siutable & 4,5 & Good \\
\hline 4. & It introduces the Government Agencies/Entities in details & 4,03 & Good \\
\hline 5. & It motivates students & 4,43 & Good \\
\hline 6. & Students can understand the learning material & 4,3 & Good \\
\hline
\end{tabular}

Table 5. The Validation Results of the Mobile-based Learning Media in Large Groups

\begin{tabular}{|c|l|c|c|}
\hline No. & \multicolumn{1}{|c|}{ Indicators } & Scores & Categories \\
\hline 1. & Easy to use & 4,28 & Good \\
\hline 2. & Can be used independently & 3,96 & Moderate \\
\hline 3. & Understandable language & 4,48 & Good \\
\hline 4. & High accessibility & 4,2 & Good \\
\hline 5. & Attractive media & 4,68 & Good \\
\hline 6. & Suitable animation & 4,32 & Good \\
\hline
\end{tabular}

The material and media aspects of LEGASI presented in Tables 4 and 5 proved that this application was feasible to use which is indicated with scores ranging between 3.96 and 4.68.

\subsection{Evaluation}

At the evaluation stage, the final revision of the product (LEGASI) was performed based on the suggestions and inputs from the students involved in the large-group trials. Students suggested that improvement was necessary to make the tools on LEGASI become more interesting. In addition, the materials found in LEGASI were consistent with the objectives of the basic competencies. Based on validation and student responses, LEGASI provides a highly feasible Android-based learning media for civic education. Through its development, this research confirmed that learning activities which utilizes technology could be performed anywhere and anytime. The ultimate goal of integrating technology and learning media is to solve problems arising from the lack of facilities in learning activities [41]. In addition, the findings in this research are relevant with the previous research findings where the use of application in learning give a lot of benefits 
such as accelerating Qurán reading fluency, improving tertiary students' speaking skills and increasing the student's learning motivation for Science subject.[42] [43] [44].

\section{Conclusions}

LEGASI is a learning media developed through five stages (ADDIE). (1) Analysis is the initial stage in which curriculum, the student's need, and the subjects are analyzed. (2) Design refers to the process of creating research instruments, designing the product (LEGASI), and uploading it to Google Play Store. (3) Development deals with developing the application, performing expert's judgement and revising. (4) Implementation includes trials on small and large groups, and (5) Evaluation is the final stage of the development procedure, which compares the results of the testing phase and concludes the feasibility of the application.

According to the material and media experts, the levels of feasibility are $89.04 \%$ and $90.78 \%$, respectively, which reflect high feasibility. LEGASI has been subjected to small-group trials as a learning media of civic education, and the responses are expressed as dimensionless scores within the range of 4.0-4.6, meaning that this application is eligible for a further test on large groups. In large-group trials, the use of LEGASI scored 3.96-4.68, confirming its high feasibility for the teaching of civic education subject. The developed application in this research focuses on a certain topic of Civic Education learning namely government institution in Indonesia therefore the future research may expand various topics of Civic Education learning. Also, the success of using the mobile application in learning is influenced by the teacher's literacy on technology. Thus, future research may investigate this problem.

\section{Acknowledgement}

The authors would like to thank the Faculty of Social Sciences, Yogyakarta State University, for funding this research as part of the group research program in the 2019 fiscal year.

\section{$7 \quad$ References}

[1] M. A. Abugohar, K. Yunus, and R. A. Rashid, "Smartphone applications as a teaching technique for enhancing tertiary learners' speaking skills: Perceptions and practices," Int. J. Emerg. Technol. Learn., vol. 14, no. 9, pp. 74-92, 2019. https://doi.org/10.3991 lijet.v14i09.10375

[2] N. Vidakis, A. K. Barianos, A. M. Trampas, S. Papadakis, M. Kalogiannakis, \& K. Vassilakis. "Generating Education in-Game Data: The Case of an Ancient Theatre Serious Game," CSEDU (1), pp. 36-43, 2019. https://doi.org/10.5220/0007810800360043

[3] I. Lestari, A. Maksum, and C. Kustandi, "Mobile learning design models for State University of Jakarta, Indonesia," Int. J. Interact. Mob. Technol., vol. 13, no. 9, pp. 152-171, 2019. https://doi.org/10.3991/ijim.v13i09.10987 
[4] W. D. Sulistyo, B. Kurniawan, and U. N. Malang, "The Development of ' JEGER ' Application Using Android Platform as History Learning Media and Model," pp. 110-122. https://doi.org/10.3991/ijet.v15i07.11649

[5] S. Papadakis, A. M. Trampas, A. K. Barianos, M. Kalogiannakis, \& N. Vidakis, "Evaluating the Learning Process: The"ThimelEdu" Educational Game Case Study," CSEDU (2), pp. 290-298, 2020 https://doi.org/10.5220/0009379902900298

[6] D. G. H. Divayana and D. B. Sanjaya, "Mobile phone-based CIPP evaluation model in evaluating the use of blended learning at school in Bali," Int. J. Interact. Mob. Technol., vol. 11, no. 4, pp. 149-159, 2017. https://doi.org/10.3991/ijim.v11i4.6796

[7] B. J. Kim, A. L. Kavanaugh, and K. M. Hult, "Civic engagement and internet use in local governance: Hierarchical linear models for understanding the role of local community groups," Adm. Soc., 2011. https://doi.org/10.1177/0095399711413873

[8] M. Saputra, and I.H.A. Siddiq, "Social Media and Digital Citizenship: The Urgency of Digital Literacy in the Middle of a Disrupted," International Journal of Emerging Technologies in Learning (iJET), vol. 15, no. 7, pp. 156-161, 2020. https://doi.org/10.3991 lijet.v15i07.13239

[9] J. A. Banks, "Diversity, group identity, and citizenship education in a global age," Educ. Res., vol. 37, no. 3, pp. 129-139, 2008. https://doi.org/10.3102/0013189X08317501

[10] C. Titus, "Civic Education untuk pemahaman global," in Belajar Civic Education dari Amerika, M. S. Branson, Ed. Yogyakarta, 1999

[11] W. C. Parker, A. Ninomiya, and J. Cogan, "Educating world citizens: Toward multinational curriculum development," Am. Educ. Res. J., vol. 36, no. 2, pp. 117-145, 1999. https://doi.org/10.3102/00028312036002117

[12] F. M. Esteve-Mon, M. Á. Llopis, and J. Adell-Segura, "Digital Competence and Computational Thinking of Student Teachers," Int. J. Emerg. Technol. Learn., vol. 15, no. 02, p. 29, 2020 https://doi.org/10.3991/ijet.v15i02.11588

[13] J. F. Matos, A. Pedro, and J. Piedade, "Integrating digital technology in the school curriculum," Int. J. Emerg. Technol. Learn., vol. 14, no. 21, pp. 4-15, 2019. https://doi.org/10.3991 lijet.v14i21.10863

[14] D. B. Morais and A. C. Ogden, "Initial development and validation of the global citizenship scale," J. Stud. Int. Educ., vol. 15, no. 5, pp. 445-466, 2011. https://doi.org/10.1177/1028315310375308

[15] S. H. Mun et al., "Active learning using digital smart board to enhance primary school students' learning," Int. J. Interact. Mob. Technol., vol. 13, no. 7, pp. 4-16, 2019. https://doi.org/10.3991/ijim.v13i07.10654

[16] P. Dorouka, S. Papadakis, \& M. Kalogiannakis, "Tablets and apps for promoting robotics, mathematics, STEM education and literacy in early childhood education," International Journal of Mobile Learning and Organisation, vol 14, no 2, pp. 255-274, 2020. https://doi.org/10.1504/IJMLO.2020.106179

[17] S. Atawneh, B. Al-Kasasbeh, and M. Ben Rshed, "Android-based mobile application for door-to-door product delivery," Int. J. Interact. Mob. Technol., vol. 13, no. 3, pp. 125-142, 2019. https://doi.org/10.3991/ijim.v12i7.9598

[18] Suryaman and H. Mulyono, "Design and use of a mobile application to prevent teachers' absenteeism in a higher education setting," Int. J. Interact. Mob. Technol., vol. 13, no. 8, pp. 4-15, 2019. https://doi.org/10.3991/ijim.v13i08.10270

[19] I. K. Wijaya, R. A. Bakri, A. A. Wutun, Fitriani, and A. A. Mattoliang, "The effectiveness of mobile learning-based android in learning English vocabularies," Int. J. Interact. Mob. Technol., no. 12, pp. 226-235, 2019. https://doi.org/10.3991/ijim.v13i12.11167 
[20] M. Kalogiannakis, G. M., Nirgianaki, and S. Papadakis, "Teaching magnetism to preschool children: The effectiveness of picture story reading," Early Childhood Education Journal, vol. 46, no. 5, pp. 535-546, 2018. https://doi.org/10.1007/s10643-017-0884-4

[21] M. Z. C. Had and R. A. Rashid, "A review of digital skills of Malaysian English language teachers," Int. J. Emerg. Technol. Learn., vol. 14, no. 2, pp. 139-145, 2019. https://doi.org/10.3991/ijet.v14i02.8732

[22] F. Sidik, "Pengguna Perangkat Mobile di Indonesia Semakin Tinggi, Ini Datanya!" 2018, [online]. Available: https://ekonomi.bisnis.com/read/20180201/101/733037/penggunaperangkat-mobile-di-indonesia-semakin-tinggi-ini-datanya

[23] C. Hursen and C. Bas, "Use of gamification applications in science education," Int. J. Emerg. Technol. Learn., vol. 14, no. 1, pp. 4-23, 2019. https://doi.org/10.3991/ijet.v14i01.8894

[24] X. Bi and X. Shi, "On the effects of computer-assisted teaching on learning results based on blended learning method," Int. J. Emerg. Technol. Learn., vol. 14, no. 1, pp. 58-70, 2019. https://doi.org/10.3991/ijet.v14i01.9458

[25] Muljono, G. W. Saraswati, N. A. S. Winarsih, N. Rokhman, C. Supriyanto, and Pujiono, "Developing BacaBicara: An Indonesian lipreading system as an independent communication learning for the deaf and hard-of-hearing," Int. J. Emerg. Technol. Learn., vol. 14, no. 4, pp. 44-57, 2019. https://doi.org/10.3991/ijet.v14i04.9578

[26] M. Kalogiannakis, \& S. Papadakis, "Combining mobile technologies in environmental education: a Greek case study," International Journal of Mobile Learning and Organisation, vol 11, no. 2, pp. 108-130, 2017. https://doi.org/10.1504/IJMLO.2017.084272

[27] Cholisin, PPKn Paradigma Baru dan Pengembangannya dalam KBM. Jakarta: PT Gramedia Pustaka Utama, 2003.

[28] H. Kirschenbaum, 100 Ways to Enhance Values and Morality in Schools and Youth Settings. Massachusetts: Allyn \& Bacon, 1995.

[29] M.N. Somantri, Menggagas Pembaharuan IPS. Bandung: Remaja Rosda Karya, 2001.

[30] BSNP. Permendiknas RI No. 22 Tahun 2006 tentang Standar Isi untukSatuan Pendidikan Dasar dan Menengah. Jakarta, 2006.

[31] Sugiyono, "Metode Penelitian Kuantitatif, Kualitatif dan R \& D. Bandung: Alfabeta.," Metod. Penelit. Kuantitatif, Kualitatif dan R D.BandungAlfabeta., 2012.

[32] N. F. Jumaat, N. Ahmad, N. Abu Samah, Z. M. Ashari, D. F. Ali, and A. H. Abdullah, "Facebook as a platform of social interactions for meaningful learning," Int. J. Emerg. Technol. Learn., vol. 14, no. 4, pp. 151-159, 2019. https://doi.org/10.3991/ijet.v14.i04.9363

[33] B. Hariadi, M. J. D. Sunarto, P. Sudarmaningtyas, and B. Jatmiko, "Hybrid learning by using brilian applications as one of the learning alternatives to improve learning outcomes in college," Int. J. Emerg. Technol. Learn., vol. 14, no. 10, pp. 34-45, 2019. https://doi.org/10.3991 lijet.v14i10.10150

[34] I. Wardani, H. Tolle, and I. Aknuranda, "Evaluation of an educational media on cube nets based on learning effectiveness and gamification parameters," Int. J. Emerg. Technol. Learn., vol. 14, no. 14, pp. 4-18, 2019. https://doi.org/10.3991/ijet.v14i14.10505

[35] H. E. Rudyanto, A. Ghufron, and Hartono, "Use of integrated mobile application with realistic mathematics education: A study to develop elementary students' creative thinking ability," Int. J. Interact. Mob. Technol., vol. 13, no. 10, pp. 19-27, 2019. https://doi.org/10.3991/ijim.v13i10.11598

[36] Y. Hanafi, H. J. Hendrawan, and I. N. Hakim, "Accelerating Qurán reading fluency through learning using QURáNI application for students with hearing impairments," Int. J. Emerg. Technol. Learn., vol. 14, no. 6, pp. 110-132, 2019. https://doi.org/10.3991/ijet.v14i06.9863 
[37] M. Z. C. Had and R. Ab Rashid, "A review of digital skills of Malaysian English language teachers," International Journal of Emerging Technologies in Learning (iJET), vol. 14, no. 02, pp. 139-145, 2019. https://doi.org/10.3991/ijet.v14i02.8732

[38] O. V. Galustyan, N. I. Vyunova, E. P. Komarova, E. S. Shusharina, S. S. Gamisonija, and O. N. Sklyarova, "Formation of media competence of future teachers by means of ICT and mobile technologies," Int. J. Interact. Mob. Technol., vol. 13, no. 11, pp. 184-196, 2019. https://doi.org/10.3991/ijim.v13i11.11350

[39] S. Papadakis, M. Kalogiannakis, \& N. Zaranis, "The effectiveness of computer and tablet assisted intervention in early childhood students' understanding of numbers. An empirical study conducted in Greece," Education and Information Technologies, vol. 23, no.5, pp. 1849-1871, 2018. https://doi.org/10.1007/s10639-018-9693-7

[40] I. Wardani, H. Tolle, and I. Aknuranda, "Evaluation of an Educational Media on Cube Nets Based on Learning Effectiveness and Gamification Parameters" International Journal of Emerging Technologies in Learning (iJET), vol. 14, no. 14, pp. 4-18, 2019. https://doi.org/10.3991/ijet.v14i14.10505

[41] Darmaji, D. A. Kurniawan, Astalini, A. Lumbantoruan, and S. C. Samosir, "Mobile learning in higher education for the industrial revolution 4.0: Perception and response of physics practicum," Int. J. Interact. Mob. Technol., vol. 13, no. 9, pp. 4-20, 2019. https://doi.org/10.3991/ijim.v13i09.10948

[42] Y. Hanafi, H. J. Hendrawan, and I. N. Hakim, "Accelerating Qurán Reading Fluency through Learning Using QURÁNI Application for Students with Hearing Impairments," International Journal of Emerging Technologies in Learning (iJET), vol. 14, no. 06, pp. 110-132, 2019. https://doi.org/10.3991/ijet.v14i06.9863

[43] M. A. Abugohar, K. Yunus, and R. Ab Rashid, "Smartphone applications as a teaching technique for enhancing tertiary learners' speaking skills: Perceptions and Practices" International Journal of Emerging Technologies in Learning (iJET), vol. 14, no. 09, pp. 74-92, 2019. https://doi.org/10.3991/ijet.v14i09.10375

[44] C. Hursen and C. Bas, "Use of gamification applications in Science Education," International Journal of Emerging Technologies in Learning (iJET), vol. 14, no. 01, pp. 4-23, 2019. https://doi.org/10.3991/ijet.v14i01.8894

\section{Authors}

Mukhamad Murdiono is an Associate Professor in Teaching Strategies of Civic Education, Faculty of Social Sciences, Universitas Negeri Yogyakarta. Email: mukhamad_murdiono@uny.ac.id

Suyato is an Associate Professor in the Teaching of Pancasila and Civic Education, Faculty of Social Sciences, Universitas Negeri Yogyakarta. Email: suyato@uny.ac.id

Elly Nur Rahmawati and Muhammad Abdul Aziz are undergraduate students, at the Department of Civic and Law Education, Faculty of Social Sciences, Universitas Negeri Yogyakarta. Email: elly.nur2016@student.uny.ac.id \& Muhammad.abdul2016@student.uny.ac.id

Article submitted 2020-04-18. Resubmitted 2020-07-02. Final acceptance 2020-07-11. Final version published as submitted by the authors. 